\title{
Reflections on South African psychology with Saths Cooper
}

\section{Brendon Barnes' and Saths Cooper ${ }^{2,3}$}

\author{
'Department of Psychology, University of Johannesburg, South Africa \\ IInternational Union of Psychological Science, South Africa \\ ${ }^{3}$ Psychology Department, University of Pretoria, South Africa

\section{Corresponding author:} \\ Brendon Barnes, Department of Psychology, University of Johannesburg, P O Box 524, Auckland Park, \\ 2006 Johannesburg, South Africa. \\ Email: bbarnes@uj.ac.za
}

\begin{abstract}
Saths Cooper, $\mathrm{PhD}$, is an important figure in both South African and international psychology. Based on a two hour interview with Cooper, this article focuses on his experiences with Apartheid-era psychologists, his views on the abuses of psychology past and present, and his views of psychology as president of the International Union of Psychological Science. While we have much to celebrate about the 20 years of Psychological Society of South Africa's existence, Cooper's experiences are a stark reminder of the complicity of the discipline with the Apartheid state machinery. Psychology needs to remain attentive to how it is organized and applied to contemporary societal issues. It is hoped that this article will stimulate further reflections about the development of the discipline in South Africa and beyond.
\end{abstract}

\section{Keywords}

Apartheid, incarceration, political, prison, psychologist, South Africa

As we reflect on 20 years of South Africa's democracy as well as 20 years of the Psychological Society of South Africa (PsySSA), the editorial team of the South African Journal of Psychology felt that it was fitting to interview Sathasivan (Saths) Cooper, $\mathrm{PhD}$, who played an instrumental role in the development of both. The interview focused on Cooper's experiences of the role of apartheid-era psychologists during his incarcerations, his views of psychology in contemporary South Africa and the discipline's connection to the global context. The discussion, therefore, was as much about the past as it was about connecting South African psychology to the continent and the rest of the world. 
Cooper's contributions to the anti-apartheid struggle have been well documented (see, for example, Kuriansky, 2013 and Dlamini, 2007). Similarly, his contributions to the development of psychology in the transition from apartheid to post-apartheid are equally noteworthy (see, for example, Cooper, 1986, 1990, 1994, 2014), and recognized by numerous awards, including the Inaugural Achievement Against the Odds Award from the International Union of Psychological Science at the International Congress of Psychology (ICP2012) and the American Psychological Association 2014 Award for Distinguished Contributions to the International Advancement of Psychology. Perhaps most impressive was Cooper's appointment as President of the International Union of Psychological Science (IUPsyS) in 2012 - the first psychologist from outside Europe and the United States, and the first from Africa, to hold this position.

We start the interview with a question about Cooper's experiences with psychologists while imprisoned.

Barnes: How aware were you of psychologists working in the prison system?

Cooper: I became aware of psychologists in the prison system when I got to Robben Island. I became aware of the person who was head of the prison. He was a counseling psychologist, Prins. He was obviously there to play the role of using his psychological skills to make determinations of what prisoners needs were (Saths explains that there were two prisons on Robben Island - a maximum security political prison and the common law criminal prison). There was a commander of the entire island, like a governor. It is interesting to note that while we have this understanding that these were all Afrikaners, English-speaking persons played a significant role in the oppressive machinery. The commander was a guy called Richards. Richards had been the commander of the Point Prison in Durban. You know there is this grouping, ... you have this group of English and this group of Afrikaans speakers and then you have this group of mixed people with English names and Afrikaans backgrounds and vice versa. Richards was of that variety and because of his fluency in English, they believed that it was better to have someone with an English background with the influx of the post-1976 youngsters.

Somewhere in about 1977 or 1978 that head who was a psychologist was moved to the commander's office and a guy from Pretoria was sent down, Harding. Harding also had a link with us because after we got convicted in Pretoria in the South African Students' Organization and Black People's Convention trial, he was the one handling the logistics for us to be transported from Pretoria to Cape Town and so, lo and behold, he is the guy that appears there. At some point in 1978 or 1979, there was a Colonel, a clinical psychologist, who was sent to Robben Island. His brief was to assess and look at the grading of prisoners - political prisoners (Saths explains the grading system from the lowest $\mathrm{D}$, with the lowest privileges, to the highest A, with most privileges, for example, more visits and letters). The warders let everyone know that if they wanted to they could talk to the psychologist. So, this Colonel would always be available for consultation or therapy, and some prisoners found him useful, particularly the older prisoners. The younger prisoners just did not bother as this guy was regarded as part of the system and therefore the enemy. He was a warder, a glorified warder, and so many people didn't bother.

My interaction with him arose when I was called up to his office to say that they had decided to give me a higher grading. And at this point, I was in the single cell section where the Mandelas and others were. I said to him that my colleagues and I do not believe in this grading system and will not participate in it. And he continued with why it was important and explained the privileges, and I said, I refuse to participate in it. The discussion was quite long, and they tried to convince me, but I remained steadfast. They said that they had decided to give this to me anyway. I said that what they decided was not my problem, but I will not participate. So it ended up with me getting a B grading (and an A grading eventually). 
Barnes: So you "accepted" the grading? You got more privileges but you resisted in principle? Cooper: I said I'm not participating in what you're doing, but the result of it was that I got more privileges (laughter). Immediately, I got a few more letters, you see. And fairly quickly of course, I used the privilege ... without participating in official grading. In a sense it, was a comprised system, but my interactions with psychologists were basically that kind of thing.

Barnes: Do you think the psychologist's complicity in the grading system was meant to divide prisoners along ideological lines.

Cooper: Oh yes. You see most of the leaders were in the single cells while most of the followers were in the general section. So they could say to the followers, "you see, you guys are resisting but you see your leaders are participating . . ." but the big issue was, were you malleable? Were you somebody who, through being offered these kinds of blandishments, they could predict how you would behave in other situations? How much of a threat were you? So it was using psychology. And the major issue for them was, are you adjusting to prison life? Are you co-operative?

Barnes: So it wasn't about how well you were doing, of course

Cooper: No, no. Are you co-operative? You know "saamwerk" (co-operation) was a big issue. "Aanpassing" (adjustment) was also a big issue. These were the big issues more than anything else. In terms of co-operation, my generation used to complain about any infringement of our basic rights we had in terms of the Prisons Act. There were regulations that said that prisoners were entitled to 1,2 , and 3. Our insistence on that got to such a point where they used to actually measure our food. They would weigh the pap. And it lasted only a few days, they stopped because it was simply impossible to do because everything would be backlogged because we insisted on at least the minimum rights. It was usual to have a "klagtes" and "versoeke" (complaints and request) book and because almost all of us would have some form of request, very soon what was a daily exercise went to once a week and then they would eventually only ask you if you had a request, monthly. They realized that here was a group of prisoners who played the system to its maximum; they had certain laws, and we insisted that they abide by those laws, such as they were.

The other interaction was with a psychologist named Jannie Roux. Roux was the Deputy Commissioner of Prisons and in charge of political prisoners. The Broederbond was an interesting organization because it was there, it was shadowy, but the Broederbond didn't push its person or its nominee into every position of control. In my experience, often what they did was to appoint the deputy head as their person. So the National Party had the opportunity to appoint the head, but the deputy was often a Broederbonder. You realize that "so and so" was head, but the deputy head controlled things. So in this case, Jannie Roux was the quintessential Broederbond appointee. He was a clinical psychologist responsible for setting up the Zonderwater sociopathic unit (a prison near Pretoria). He had the penchant for arriving in Robben Island unannounced in terms of prisoner interaction. My first interaction with Jannie Roux was in 1977, and again, we were in the punishment block single cells because we refused to work in the quarry under unsafe conditions. At about $21 \mathrm{~h} 00$ or so, the cells were opened and they said "die Kommissaris is hier" they always referred to him as the Kommissaris, not the deputy Kommissaris. Do you have klagtes (complaints) and versoeke (requests) vir die Kommissaris? My cell was sort of in the middle of this line of cells. There were guys who said they were not interested. Then they came to me and I said okay. I had wanted to see who these guys were ... this Kommissaris, this psychologist.

Barnes: Had you known that you wanted to be psychologist then?

Cooper: It was developing . . . it was developing. The other issue was that I hadn't been out of the single cell section and out in the dark for a long time. This was something new. I've never been afraid to engage with anybody. In the engagement, not to engage was always my right. If I want to meet you that's fine, but if I want to take it further, that's up to me. So I arrived there, and there is 
Muntu Myeza, Strini Moodley and Aubrey Mokoape (fellow political prisoners). Roux is a short guy, just over 5 feet, balding as well. His feet are on the prison table with a cheroot, puffing away. There is a heated discussion with Aubrey holding forth, very emotionally. Muntu or Strini tells me that Aubrey is going on about being a medical doctor and the warders call him "Hey, jong" and all sorts of demeaning phrases. They refuse to acknowledge that he is a medical doctor. And Roux is puffing away at his cheroot totally ignoring Aubrey. I interrupt and Aubrey looks at me and is angry that I interrupted him. I say to Roux, "I haven't studied Afrikaans, I haven't done it in school" which is true, because I came through the Natal Education Department. Afrikaans was an option, and I chose Latin because you could do lots of things with it, medicine, law, etc. I said to Roux that "I didn't study Afrikaans, but I have learnt Afrikaans over the years that I have been prison. Let me tell you the Afrikaans that I have come to know in prison." (Saths explains some of the rude words he had come to learn in prison). He immediately took his feet off the desk, cheroot out of his mouth and said "henceforth everyone will have a name tag and you will call every prisoner by his name or number" (laughter).

I subsequently engaged with Roux and in that conversation asked him about the Zonderwater thing. He gave me a description about how it was working and these prisoners were very compliant and the outcomes were very good. What I saw immediately was the prisoners manipulating that system to show good behavior. And I said, "Are you sure this was an outcome or were they just trying to please you?" You know, we all know prison experiments, how you want to please those in charge to get whatever you want to get. So those were my interactions with Roux. He often accompanied important guests to the prison like the Red Cross, Helen Suzman or maybe a judge. He would always be around making sure that things were okay so whenever such people visited they wouldn't get negative feedback.

My next interaction with a prison psychologist was when Mandela and the Rivonia trialists were removed to Pollsmoor prison. Within a few days I, together with my co-accused and a few others, were moved to Victor Verster prison (April 1982). And at that time, talk was rife that people would get released provided that there was "saamwerk" and "aanpassing" and so forth . . . So we were writing exams, and during the exam time, someone arrives to interview people. Most of my fellow inmates refuse to meet this guy. I see this as a diversion to studying so I go to see who this guy is. He asks me what I want to do after prison. I say I want to do psychology, and he says that psychology would be very good for your organization- " "you would be able to see who the guys who are collaborators are and pick them out." I said, "I hadn't thought of it that way but now that you mentioned it ..." The discussion continued. By the end of that, he said "I must tell you that I am a psychologist and I have been sent to assess you for pre-release." It was November 1982, and the next month, I was going to be released. But this came right at the end, and he made whatever findings he made. And that has been my direct interaction with the known psychologists.

Those that I have not known, I can't comment on. Because, as you know, a large number of psychologists were employed in state departments. It is interesting that during the post-apartheid era, the number of psychologists (in state departments) diminished drastically and a large number of those became private practitioners. A part of the agitation on categories and so forth come from those people.

Barnes: You mean agitation about professional categories?

Cooper: Yes, because a lot of them got dispensations to become psychologists in the service of the state.

Barnes: What about psychologists and torture in prisons at the time? 
Cooper: I did not know of any psychologists who would have been working within prisons and security police at the time who were in involved in torture. BUT the techniques that they used were clearly techniques that were tried and tested. For example, good-cop/bad-cop, trying to work his way into your sensibilities. I cannot say that psychologists directly participated in torture like has happened with the American military and the controversy within the American psychology fraternity on that issue.

Barnes: In your capacity as president of IUPsyS, where do you see psychology going globally and what are the implications for South African psychology?

Cooper: There has been a burgeoning of psychology over the last 18 months because, post ICP2012, people have seen that the psychology that exists in South Africa can hold its own. Despite the heavy practice orientation, there is serious attempt to ground psychology in the sciences. In the next few years, we are going to be inundated with conferences like we have already been. South Africa is a firm member of the International Union, but it is amazing how many other countries, both western and from the global south, have looked to South Africa to unpack issues that have just been stalemated in a sense.

We have access to a veritable human laboratory of behaviors that we have not come to understand. And we have to take advantage of that in its multicultural richness, in its violence and daily stress ridden conditions but also in its propensity for resilience. So a lot of people will, I think, start taking lessons from South Africa if we continue to play those leadership roles. Already, we have sizeable bodies of thought in psychology that are groundbreaking. We need to extend those to other areas, for example, development in education, in policy, in new interventions through our understanding of fellow South Africans.

We should also make psychology more in tune with the realities we face. I am not saying find a different psychology, but the psychology we end up with should have an element of proudly South African ... South Africa, warts and all ... so that we are not presenting only the negatives. It is easier to do research on the negatives. There are positives too. For example, we are the only country I know of where the salaries of psychologists are on par with doctors and dentists in the public sector. There are so many other firsts that we've got despite the terrible history of apartheid.

So we've got that history. In the Truth and Reconciliation Commission, there were devastating findings against the health professions. Psychology did not really present a picture of what it did to entrench apartheid. I was a member of the Board for Psychology, and I made the representations to the Reparations Committee. I remember saying that psychology has a long way to go but we are aware of these and we have to deal with these realistically. We cannot make excuses for our past, what happened in the past is there, but it is a route marker for what we should not do. That's why I think in PsySSA now, we are aware that people are also political beings, they are social beings, but PsySSA as the national society cannot be the hand-maiden of any party political agency out there, which is what happened in the past. People look at that and see that we are principled and that we can do things differently.

So from an ethical point of view, we cannot make excuses for the abuse of psychology. We should work to avoid any abuse of psychology. But we are not seeing such abuse at a political level where decisions are taken that are influenced by psychology, where we are seeing it is at the public level. For example, a lot of psychologists who work for trial lawyers end up being hired guns. So, we've got the Modimole case where the psychologist went out of her way to attempt to exonerate the accused, trying to show diminished responsibility, and in the Oscar Pistorius trial, the psychologist apparently wiping the tears off Oscar's face. That is not the job of a psychologist. I think that we have not grounded our professionals in an ethical basis of working in a manner that does not compromise (1) their own integrity as a professional and (2) the integrity of the profession. For example, people fight about why their diagnosis of an accused or of the patient is correct. I find that 
repugnant. I think we should have a panel and make that panel available to court and say "choose your expert." You are an expert to the court. How can we do that if we constantly are employed by one or the other side? That is a battle that needs to be fought.

Coming back to the Oscar Pistorius trial, we also ought to be saying to lawmakers that you should not give people the right to arms unless they have gone through a proper and objective psychological assessment to show that these are, indeed, people without the kinds of problems that clearly Oscar has and clearly that a lot of gun owners have. Illegal arms are a different story, but for legal arms, there is provision for assessment that we have not taken up. It is those kinds of things that we need to do.

Globally, psychology is booming. In my stint now as president of IUPsyS, I have had the opportunity to visit many places, and psychology is alive and well. In places like Colombia, where the similarities with South Africa are high, to become a clinical psychologist you need 5 years of university study and then only do you do a further degree. Most countries have a 4-year undergraduate degree, and we have 3. If we were to look at reconfiguring that, and then looking at creating other levels of service providers, we won't find psychologists doing the frenetic things that a small minority are doing now to get more money. We have also reached an agreement with the Department of Education to create a pilot program for school counselors and that is in the offing.

Barnes: When will that roll out?

Cooper: Possibly next year. We are putting the final touches to the agreement in the next few weeks.

Barnes: Reading up on your life and your political views, I have always seen you as a person who has always bucked the system and who has been critical of mainstream. Yet you are at the helm of what some might consider to be a mainstream organization. How do you reconcile the radical Saths Cooper of the past with Saths Cooper now?

Cooper: I'm still regarded as a radical in international psychology circles. My election was also different in that it was the first time that someone had won in the first round of voting. I won by a landslide because I don't conform to certain notions of what a scientific psychologist should be. And that basically comes down to one issue only, the number of publications. Even when I taught there were opportunities to write, but I would always collaborate. I also don't believe that a psychologist should be a know-it-all, and it is always good to refer to someone else who has more expertise. In my leadership style, I can be very strong and rough when the time arises, but I also have the patience, which I didn't have then, to allow certain things to happen. I won't dot the "is" and cross the "ts." I'm still a little OCD, but I don't do that as much. I involve other colleagues a lot in projects, and I do more joint things than individual things. At the same time what colleagues are saying in parts of the world, including North America and Western Europe, is that this is a difference in leadership in international psychology.

I think there will be a new era in psychology globally, and what Mao did not succeed to do to "allow 100 flowers to blossom" psychology can, in that no one theory is true and correct. No theory has the necessary and sufficient conditions to describe all of human behavior. But it is also a time that the divide between science and practice is being narrowed so that the old bifurcation doesn't haunt us in the future. Because that is where we've lost the prize on impacting on policy makers and changing policy makers to make decisions. So what they (policy makers) do is rely on economists who have failed the world, rely on medicine and other areas to explain behavior which we should be leading. So we've given up that place which we must reclaim.

In the International Union, my mission now is to say that psychology underpins everything else in society. The Union is the global voice of psychology which is now 125 years old, and we should be developing psychology in parts of the world, where, if we don't participate, if we ignore it, it 
will assume a Hindu or a Muslim or a Buddhist or narrow Christian face, which is not psychology. There is no area of human endeavor which does not rely on psychology.

\section{Concluding remarks}

Even though I (the first author) had read about some of Saths Cooper's experiences with apartheid psychologists and the apartheid state more generally, it was both interesting and sobering to hear them first-hand. It was also interesting to get Cooper's views on the current state of South African psychology and international psychology more broadly. However, South African psychology has to remain vigilant about ways in which the discipline is inadvertently reinforcing injustice. While we may fail to agree with some of the sentiments and suggestions made by Saths, fail to agree on what the role of psychology in society should be, and even whether psychology should strive for a more scientific basis, it is clear that South African psychology is in a space where fundamental issues affecting the discipline can be debated and dialogued. For this, we can only be grateful.

\section{Funding}

This research received no specific grant from any funding agency in the public, commercial, or not-for-profit sectors.

\section{References}

Cooper, S. (1986). Participation is playing with toy telephones. In J. A. Du Pisani (Ed.), Divided or united power: Views on the new constitutional dispensation by prominent South African political leaders (pp.194-205). Johannesburg, South Africa: Lex Patria.

Cooper, S. (1990). The psychological impact of political imprisonment and the role of the psychologist. In L. J. Nicholas \& S. Cooper (Eds.), Psychology and apartheid: Essays on the struggle for psychology and the mind in South Africa (pp. 140-144). Johannesburg, South Africa: Vision.

Cooper, S. (1994). Political violence in South Africa: The role of youth. A Journal of Opinion, 22, 27-29.

Cooper, S. (2014). The Mandela I knew. South African Journal of Psychology, 44, 3-5.

Dlamini, V. (2007). Podcast: Saths Cooper on Steve Biko, the history of South Africa and the psychology of race. Retrieved from http://victordlamini.bookslive.co.za/blog/2007/10/09/podcast-saths-cooper-onsteve-biko-the-history-of-south-africa-and-the-psychology-of-race/

Kuriansky, J. (2013). Nelson Mandela and Saths Cooper: Two generations of anti-apartheid activists share a prison cell block and become a president. Retrieved from http://www.huffingtonpost.com/judy-kuriansky-phd/nelson-mandela-and-saths-_b_4442634.html 